\title{
Pembuatan Akta Ikrar Wakaf di Kecamatan Rasau Jaya (Tinjauan Regulatif dan Implementatif)
}

\author{
Waskur, S.Pd., S.H.I., M.M. \\ Sekolah Tinggi Ilmu Syariah Syarif Abdurrahman Pontianak \\ J1. Sungai Raya Dalam No.16, Bangka Belitung Laut, Kecamatan Pontianak Tenggara, Kota \\ Pontianak, Kalimantan Barat 78117 \\ Email: waskurruksaw@gmail.com
}

\begin{abstract}
Submitted $\quad: 8$ November 2021
Revised : 2 Desember 2021

Accepted : 5 Desember 2021

Published : 18 Januari2022

Jurnal Al Adl by Universitas Islam Kalimantan Muhammad Arsyad albanjari is licensed under a Creative

Commons Attribution 4.0 International License. (CC-BY)
\end{abstract}

\begin{abstract}
The regulation of waqf in Indonesia has been well-developed, following the enactment of Law Number 41 of 2004 concerning Waqf. However, problems arose in the implementation phase. These are indicated by the number of waqf lands that have not been registered for the Waqf Pledge Deed to the Officials Maker of Waqf Pledge Deed (PPAIW) at the Office of Religious Affairs. Based on observations conducted by researchers in Rasau Jaya District, it is proved that there were still many mosques whose lands have not been registered with the Office of Religious Affairs. By using the juridical-empirical research method, the author questions more about the arrangement of the waqf pledge deed in Indonesia, as well as its implementation at the author's research site - i.e. the Rasau Jaya sub-district. It can be concluded that the problems arose due to several reasons - Lack of public awareness of the importance of the Waqf Pledge Deed, considering the majority of local people are farmers who think that waqf only has a worship value and they do not comprehend the upcoming consequences, and the lack of legal counseling on waqf carried out by KUA of Rasau Jaya District. Based on the problems and data obtained, it is known that the KUA of Sungai Raya Sub-district made an effort to involve extension workers and the village government in conducting legal counseling on waqf in Sungai Raya District to reach the surrounding area of the village and improving the regulation of waqf lands registration.
\end{abstract}

Keywords: Deed of Waqf Pledge; Office of Religious Affairs; Rasau Jaya District.

\begin{abstract}
Abstrak
Pengaturan wakaf di Indonesia sudah menunjukkan perkembangan yang sangat baik, menyusul diundangkannya Undang-Undang Nomor 41 Tahun 2004 tentang Perwakafan. Namun, permasalahan muncul dalam tahap implementasi. Hal ini ditunjukkan oleh banyaknya tanah wakaf yang belum melakukan pendaftaran Akta Ikrar wakaf kepada Pejabat Pembuat Akta Ikrar Wakaf (PPAIW) di Kantor Urusan Agama. Berdasarkan observasi yang Peneliti lakukan di Kecamatan Rasau Jaya, diketahui bahwa masih banyak Masjid yang tanahnya belum didaftarkan ke Kantor Urusan Agama. Dengan menggunakan metode penelitian yuridis-empiris penulis mempersoalkan lebih dalam pengaturan akta ikrar wakaf di Indonesia, serta implementasinya pada locus penelitian penulis, yakni kecamatan rasau jaya. Kesimpulan yang didapat permasalahan muncul dikarenakan beberapa sebab, antara lain: Kurangnya kesadaran masyarakat akan pentingnya Akta Ikrar Wakaf mengingat mayoritas masyarakat setempat yang bekerja sebagai Petani beranggapan bahwa wakaf hanya bersifat nilai ibadah saja dan tidak melihat konsekuensi kedepannya serta kurangnya penyuluhan hukum perwakafan yang dilaksanakan oleh KUA Kecamatan Rasau Jaya. Berdasarkan permasalahan dan data yang di dapat, diketahui bahwa KUA Kecamatan Sungai Raya melakukan upaya dengan melibatkan penyuluh bersama dengan pemerintahan Desa untuk melakukan penyuluhan hukum perwakafan di Kecamatan Sungai Raya sampai menjangkau ke tingkat desa di sekitarnya dan perbaikan regulasi pencatatan tanah wakaf.
\end{abstract}

Kata kunci: Akta Ikrar Wakaf; Kantor Urusan Agama; Kecamatan Rasau Jaya. 


\section{PENDAHULUAN}

Seiring perkembangan zaman, wakaf memainkan peran yang sangat penting dalam pembangunan ekonomi di Indonesia. Wakaf hadir sebagai salah satu alternatif perputaran kekayaan untuk mencapai pembangunan ekonomi Indonesia yang lebih baik. Terutama dengan lahirnya Undang-undang Nomor 41 Tahun 2004 tentang Wakaf (untuk selanjutnya disebut UU 41/2004), bidang wakaf dapat difungsikan ke arah peningkatan kesejahteraan sosial ekonomi umat. UU 41/2004 memuat aturan pelaksanakaan dan pengelolaan wakaf yang wujud harapan pemerintah terhadap pengelolaan wakaf yang dinamis sesuai dengan perubahan yang terjadi di dalam masyarakat. ${ }^{1}$

UU 41/2004 ini menjadi kesempatan baik dalam pemberdayaan wakaf secara produktif karena di dalamnya terkandung pemahaman yang menyeluruh dengan diimbangi acuan manajemen pemberdayaan kapasitas wakaf secara mutakhir, meliputi penataan administrasi wakaf yang memberi kepastian hukum bagi wakif (pewakaf), nazhir (pengelola) dan maukuf'alaih (objek wakaf) serta mendorong pemanfaatan aset-aset wakaf yang tidak produktif menjadi berdayaguna dan berhasilguna.

Secara historis, sebelum lahirnya UU ini, masyarakat menggunakan ketentuan atau kebiasaan yang terdapat dalam ajaran agama Islam atau adat istiadat setempat seperti kebiasaan melakukan perbuatan hukum perwakafan tanah secara lisan yang dilakukan atas dasar kepercayaan kepada seseorang atau lembaga tertentu. Dari segi jenis ${ }^{2}$, wakaf di Indonesia lebih banyak berupa tanah yang dibangun untuk keperluan masjid, mushalla, madrasah, pesantren, makam, dan rumah yatim piatu. Ada juga berupa tanah persawahan dan perkebunan, namun karena terbatasnya kemampuan dan sempitnya pemahaman terhadap wakaf itu sendiri, mengakibatkan banyak tanah wakaf yang tidak produktif.

Secara praktis, Islam mengenal adanya lembaga wakaf sebagai sumber aset yang dapat memberikan kemanfaatan yang berkelanjutan. Sebagai contoh, di negara-negara muslim, wakaf telah diatur secara baik sehingga mempunyai peran yang signifikan untuk mensejahterakan kehidupan masyarakat. Berkaca ke dalam negeri, pengelolaan dan pendayagunaan harta wakaf (produktif) masih sangat jauh tertinggal dibandingkan dengan negara-negara muslim lainnya. Potensi wakaf di Indonesia yang seharusnya dapat menjadi

\footnotetext{
${ }^{1}$ Nurhidayani dkk, (2017), "Pengelolaan dan Pemanfaatan Wakaf Tanah dan Bangunan”, Maqdis: Jurnal Kajian Ekonomi Islam, Volume 2 Nomor 2, Juli-Desember 2017, hlm.163-175.

${ }^{2}$ Mochlasin, (2014). Manajemen Zakat dan Wakaf di Indonesia, Salatiga: STAIN Salatiga Press, hlm. 88.
} 
alternatif peningkatan kesejahteraan sosial masyarakat belum sepenuhnya dikelola secara serius. Di sisi lain itu data wakaf yang ada belum dapat dikatakan akurat mengingat data tentang asset wakaf tidak terkoordinir dengan baik dan terpusat dalam satu institusi yang profesional.

Untuk mewujudkan lembaga wakaf yang profesional, diperlukan pengelolaan yang berbasis pada manajemen, terutama berkaitan dengan kesediaan lembaga dalam membuka data dan informasi pengelolaan wakaf, mulai dari proses fundrising hingga pendistribusian hasil wakaf. Unsur utama dalam profesionalitas itu ditandai dengan diutamakannya prinsip akuntabilitas. ${ }^{3}$ Selain itu kunci pengelolaan wakaf terletak pada eksistensi pengelola wakaf ${ }^{4}$, terutama nadzir dan tim kerja yang solid untuk memaksimalkan peran wakaf.

Problem lain yang seringkali ditemukan di lapangan adalah tanah wakaf digunakan untuk sarana ibadah namun tidak disertai dengan kelengkapan dokumen yang sesuai dengan prosedur serta ketentuan peraturan perundang-undangan yang berlaku. Hal serupa jamak dijumpai di berbagai tempat di Indonesia, termasuk Kecamatan Rasau Jaya ${ }^{5}$ yang menjadi locus dalam penelitian ini.

Dari sisi sumber daya manusia, ditenggarai bahwa para nazhir belum cukup profesional untuk mengelola tanah wakaf dimaksud. Padahal, harta benda wakaf jika dikelola dan dikembangkan secara produktif, dapat digunakan sebagai salah satu jalan keluar dalam membantu menanggulangi kemiskinan di Indonesia. ${ }^{6}$ Menteri Agama pernah mengatakan bahwa kualitas dari sumber daya manusia pada lembaga wakaf secara akademik dan manajerial dinilai masih kurang. ${ }^{7}$ Pada bagian manajerial berkaitan dengan kemampuan nazhir dalam membangun lembaga wakaf yang dapat dipertanggungjawabkan.

Kemudian kurangnya sosialisasi hukum yang dilakukan Kantor Urusan Agama setempat yang bisa dikatakan pasif dalam menyampaikan informasi terkait proses pendaftaran Akta Ikrar Wakaf. Dampaknya adalah praktik wakaf yang ada di kecamatan Rasau Jaya masih

\footnotetext{
${ }^{3}$ Sherafat, (2011), “Akuntabilitas Lembaga Pengelola Wakaf”, Jurnal Walisongo, Volume 19 Nomor 1, hlm. 76.

${ }^{4}$ Sherafat Ali Hasymi, (1987), “Management of Waqf: Past and Present,” dalam Hasmat Basyar (ed.), Management and Development of Auqaf Properties, Jeddah: Islamic, Research and Training Institute and Islamic Development Bank, hlm. 21.

${ }^{5}$ Hasil penelusuran dari salah satu Dosen Sekolah Tinggi Ilmu Syariah Syarif Abdurrahman Pontianak yang melakukan penelitian dalam Pengabdian Kepada Masyarakat di Kecamatan Rasau Jaya, Desa Rasau Jaya pada tahun 2019, diketahui bahwa ada \pm 11 Masjid yang belum didaftarkan ke KUA untuk dibuatkan Akta Ikrar Wakaf dan tidak mempunyai Sertipikat Tanah Wakaf.

${ }^{6}$ Ibid.

${ }^{7}$ Situs Kementrian Komunikasi dan Informatika Republik Indonesia http://www.depkominfo.go.id. (diakses pada Selasa, 02 Maret 2021 pukul 22.30 WIB).
} 
belum berjalan sebagaimana mestinya, dikarenakan masyarakat yang enggan mengurus tanah wakafnya dan dalam berbagai kasus yang terjadi terhadap tanah wakaf masih menimbulkan berbagai konflik. Berbagai permasalahan di atas, baik secara langsung maupun tidak langsung dapat mengganggu tugas utama dalam mengelola aset wakaf di wilayah Kantor Urusan Agama Kecamatan Sungai Raya.

Selain itu, kurangnya kepedulian pemerintah terhadap masyarakat dan PPAIW. ${ }^{8}$ Tidak adanya perhatian dari pemerintah setempat dalam memberikan solusi/penyuluhan tentang pemberdayaan tanah wakaf. Pemerintah perlu kerjasama dalam membina dan membimbing masyarakat, agar mereka tahu dan paham akan pentingnya mendaftarkan tanah wakaf serta mereka akan mendapatkan kepastian hukum dari tanah yang dijadikan tanah wakaf tersebut, dan pemerintah juga seharusnya turut berperan serta dalam pensertifikasian wakaf sehingga tidak terjadi kisruh dikemudian hari.

Berdasarkan paparan di atas, Penulis tertarik untuk mendiskusikan permasalahan tersebut dengan merumuskan judul: Pembuatan Akta Ikrar Wakaf Di Kecamatan Rasau Jaya (Tinjauan Regulatif dan Implementatif).

\section{RUMUSAN MASALAH}

Berdasarkan latar belakang yang telah diuraikan sebelumnya, maka ditarik rumusan masalah sebagai berikut:

1. Bagaimana Pengaturan Akta Ikrar Wakaf dalam Hukum Positif di Indonesia?

2. Bagaimana Implementasi Proses Pembuatan Akta Ikrar Wakaf Di Kantor Urusan Agama Kecamatan Rasau Jaya?

\section{METODE PENELITIAN}

Metode penelitian merupakan cara melakukan sesuatu dengan memfokuskan pikiran secara seksama untuk mencapai suatu tujuan dengan cara mencari, mencatat, merumuskan dan menganalisis sampai dengan menyusun suatu laporan. ${ }^{9}$ Permasalahan yang dirumuskan di atas akan dijawab dengan menggunakan pendekatan yuridis empiris. Pendekatan yuridis (hukum dilihat sebagai norma atau das sollen), karena dalam membahas permaslahan

${ }^{8}$ Etika Rahmawati, (2020), "Pendampingan Pembuatan Akta Ikrar Wakaf Bagi Masjid-Masjid di Wilayah Kecamatan Rasau Jaya Kabupaten Kubu Raya Kalimantan Barat". Al Khidmat : Jurnal Ilmiah Pengabdian Kepada Masyarakat, Volume 3 Nomor 1, hlm. 47.

${ }^{9}$ Cholid Narbuko dan Abu Achmadi, (2003), Metodologi Penelitian, Jakarta: PT. Bumi Aksara, hlm. 1. 
penelitian ini menggunakan bahan-bahan hukum (baik hukum yang tertulis ${ }^{10}$ atau bahan hukum yang tidak tertulis ${ }^{11}$ ). Sedangkan makna empiris di sini mengacu pada hukum sebagai kenyataan sosial, kultural atau das sein. Penelitian ini juga disebut sebagai jenis penelitian hukum sosiologis atau dikatakan juga sebagai penelitian secara lapangan yang mengkaji ketentuan hukum yang berlaku serta yang telah terjadi di dalam kehidupan masyarakat. ${ }^{12}$ Penelitian ini merupakan penelitian yang dilakukan terhadap keadaan sebenarnya atau keadaan nyata yang telah terjadi di masyarakat dengan maksud untuk mengetahui dan menemukan fakta-fakta dan data yang dibutuhkan. ${ }^{13}$ Jadi, pendekatan yuridis empiris dalam penelitian ini maksudnya adalah dalam menganalisis permasalahan yang ada dilakukan dengan cara memadukan bahan-bahan hukum data sekunder dengan data primer yang diperoleh di lapangan yaitu mengenai efektivitas proses pembuatan akta ikrar wakaf di Kantor Urusan Agama Kecamatan Sungai Raya, baik itu mengenai lingkup pelaksanaan proses pembuatan akta ikrar wakaf serta sumber daya manusia dan manajerial di Kantor Urusan Agama tersebut. Dengan pendekatan tersebut di atas, dianalisis berbagai muatan peraturan perundang-undangan khususnya Undang-Undang Nomor 41 Tahun 2004 tentang Wakaf.

Dalam penelitian ini, pendekatan yuridis-empiris (non-doktrinal) memandang hukum sebagai gejala sosial yang empiris sifatnya sebagai variabel bebas/sebab yang menimbulkan pengaruh dan akibat pada berbagai aspek kehidupan sosial. Penelitian ini menggunakan jenis penelitian kualitatif. Di mana data yang terkumpul akan diolah dan dianalisis secara deskriptif. Penelitian kualitatif merupakan penelitian yang menekankan pada proses yaitu tidak menjadikan hasil penelitian sebagai orientasi keberhasilan suatu data melainkan kebenaran dari hipotesis yang disajikan melalui hasil penelitian gejala sosial yang ada. Pendekatan kualitatif adalah pendekatan dengan menggunakan data yang berupa kalimat tertulis atau lisan, peristiwa-peristiwa, pengetahuan yang bersifat deskriptif. ${ }^{14}$

Sumber data merupakan hal yang paling penting di dalam proses penelitian. Sumber data yang relevan merupakan cerminan dari integritas informasi yang ada di dalam penelitian. Pada penelitian ini, sumber data yang digunakan adalah data primer dan data sekunder. Data primer yaitu data yang diperoleh langsung dari sumber data yang merupakan data yang pokok

\footnotetext{
${ }^{10}$ Hukum yang tertulis adalah hukum yang dibuat oleh pejabat yang berwenang dan berlaku umum dengan ancaman sanksi yang tegas.

${ }^{11}$ Hukum tidak tertulis adalah hukum yang berlaku dalam masyarakat, yang ditaati dan diikuti sebagai pedoman hidup bermasyarakat.

${ }^{12}$ Bambang Waluyo, (2002), Penelitian Hukum dalam Praktek, Jakarta: Sinar Grafika, hlm. 15.

13 Ibid.

${ }^{14}$ Robert K. Yin, (1998 \& 2009), Studi Kasus: Desain dan Metode, Terjemahan, Jakarta: PT. Grafindo
} Persada, hlm. 2. 
atau yang utama dalam penelitian ini. Dalam hal ini sumber data yang di maksud adalah Para pihak yang berkenaan langsung dengan proses pembuatan Akta Ikrar wakaf di Kantor Urusan Agama Kecamatan Rasau Jaya, Kabupaten Kubu Raya. Sedangkan data sekunder merupakan data tambahan yang digunakan untuk melengkapi data primer. Data sekunder diperoleh dari literatur yang berhubungan dengan wakaf, seperti dari buku, jurnal, karya ilmiah, serta Undang-undang Nomor 41 tahun 2004 tentang wakaf.

Lokasi penelitian merupakan objek penelitian di mana kegiatan penelitian ini dilakukan. Penentuan lokasi penelitian dimaksudkan untuk mempermudah atau memperjelas lokasi yang menjadi sasaran dalam penelitian. Lokasi yang dijadikan objek dalam penelitian ini berada di Kantor Urusan Agama Kecamatan Rasau Jaya. Wilayah Kecamatan Rasau Jaya terdapat masjid-masjid yang didirikan atau dibangun tetapi belum memiliki Akta Ikrar Wakaf. Hal ini dikarenakan kurangnya pengetahuan masyarakat terhadap wakaf itu sendiri. Mayoritas masyarakat di Indonesia khususnya masyarakat Rasau Jaya belum banyak mengenal eksistensi dari wakaf itu sendiri padahal secara fungsional wakaf merupakan solusi bukan hanya bersifat ibadah keagamaan saja tetapi dapat memberikan pelayanan dan fasilitas dalam kegiatan ruang publik yang semakin luas. Dari segi pendidikan masyarakat yang berada di Kecamatan tersebut juga terdapat kurangnya kesadaran hukum untuk mengetahui arti penting dari Wakaf.

Teknik pengumpulan data yang dilakukan di dalam penelitian ini adalah observasi, wawancara (interview) dan dokumentasi. Observasi adalah pengumpulan data dengan cara pengamatan secara langsung pada lokasi penelitian. Tujuannya adalah untuk mengetahui keadaan sebenarnya di lapangan. Wawancara ${ }^{15}$ (interview) merupakan kegiatan atau metode pengumpulan data yang dilakukan dengan bertatapan langsung dengan responden, sama seperti penggunaan daftar pertanyaan. Wawancara bertujuan untuk mendapatkan data dengan cara mendapatkan keterangan secara lisan dari responden. Sedangkan dokumentasi ${ }^{16}$ adalah teknik atau metode pengumpulan data dengan cara mengambil data dari dokumen-dokumen yang ada baik berupa catatan, transkip, agenda maupun yang lainnya. Dokumentasi ini penting karena memuat dokumen-dokumen yang tidak dipublikasikan di media masa.

Teknik yang digunakan untuk pengujian keabsahan data adalah triangulasi sumber. Teknik triangulasi sebagai teknik untuk mengecek keabsahan data, dalam pengertiannya

\footnotetext{
${ }^{15}$ Mochtar Daniel, (2002), Metode Penelitian Sosial, Jakarta: Bumiaksara, hlm. 143.

${ }^{16}$ Suharsimi Arikunto, (2010), Prosedur Penelitian Suatu Pendekatan Praktik, Jakarta: Rineka Cipta, hlm. 236.
} 
triangulasi adalah teknik pemeriksaan keabsahan data yang memanfaatkan sesuatu dalam membandingkan hasil wawancara terhadap objek penelitian. Triangulasi ${ }^{17}$ dengan sumber artinya membandingkan dan mengecek balik derajat kepercayaan suatu informasi yang diperoleh melalui waktu dan alat yang berbeda dalam penelitian kualitatif.

\section{PEMBAHASAN}

\section{Akta Ikrar Wakaf dalam Hukum Positif di Indonesia}

Wakaf adalah perbuatan hukum seseorang atau kelompok orang atau badan hukum yang memisahkan sebagian dari benda miliknya guna kepentingan ibadah atau keperluan umum lainnya sesuai dengan ajaran islam. ${ }^{18}$ Berdasarkan Pasal 1 Undang-Undang Nomor 41 Tahun 2004 tentang Wakaf adalah perbuatan hukum wakif untuk memisahkan dan/atau menyerahkan sebagian harta benda miliknya untuk dimanfaatkan selamanya atau untuk jangka waktu tertentu sesuai dengan kepentingannya guna keperluan ibadah dan/atau kesejahteraan umum menurut syariah. ${ }^{19}$ Dalam perkembangannya wakaf dengan objek tanah semakin mendapat pengukuhan dan dilindungi oleh Undang-Undang di Indonesia. Hal ini dapat ditandai dengan pembaharuan Hukum Agraria yang sesuai dengan alam kemerdekaan Indonesia, sebagaimana dimaksud dalam ketentuan Pasal 49 Ayat (3) Undang-Undang Nomor 5 Tahun 1960 tentang peraturan Dasar Pokok-pokok Agraria (UUPA) yang menyatakan: "Perwakafan tanah milik dilindungi dan diatur dengan Peraturan Pemerintah". ${ }^{20}$

Antusias masyarakat terhadap pelaksanaan wakaf telah menarik perhatian Pemerintah untuk mengatur tentang pengelolaan wakaf, sebagai salah satu sektor untuk membangun solidaritas sosial dan ekonomi masyarakat. Wakaf merupakan potensi sumber dana umat yang perlu dikembangkan, didayagunakan, dan dikelola secara profesional untuk memperoleh hasil manfaat yang optimal dalam rangka mengentaskan kemiskinan dan mensejahterakan umat. ${ }^{21}$ Saifuddin Noorhadi dalam disertasinya, melihat hubungan regulasi hukum wakaf dan hukum

\footnotetext{
${ }^{17}$ Michael Quinn Patton, (1987), Triangulasi dalam Moleong (Ed.), Metode Penelitian Kualitatif Edisi Revisi, Cetakan ke-29, Bandung: PT. Remaja Rosdakarya, hlm. 327-331.

18 Direktorat Jendral Bimbingan Masyarakat Islam, (2006), Perkembangan Pengelolaan Wakaf di Indonesia, Jakarta: Departemen Agama RI, hlm. 163.

${ }^{19}$ Direktorat Jendral Bimbingan Masyarakat Islam, (2013), Himpunan Peraturan Perundang-Undangan Tentang Wakaf, Jakarta: Kementrian Agama RI, hlm. 2.

20 Zulfirman, (2003). "Wakaf Dalam Perundang-Undangan di Indonesia", Makalah Seminar Internasional Wakaf Sebagai Badan Hukum Privat, diselenggarakan di Medan tanggal 6-7 Januari 2003, hlm. 5.

${ }^{21}$ Solikhul Hadi, (2017), "Pemberdayaan Ekonomi Melalui Wakaf", Jurnal Zakat dan Wakaf (Ziswaf), Volume 4 Nomor 2, hlm. 230.
} 
agraria nasional. ${ }^{22}$ Dalam disertasinya yang berjudul “ Wakaf dalam Perspektif Hukum Agraria Nasional" mengatakan bahwa wakaf memiliki dimensi ganda; dimensi keagamaan dan kesejahteraan. Pengaturan tentang wakaf dalam Perundang-undangan telah dilakukan di Indonesia sejak jaman penjajahan hingga saat ini. Di Indonesia, intervensi pemerintah terhadap perwakafan baru dimulai pada tahun 1977 yang ditandai dengan lahirnya Peraturan Pemerintah Nomor 28 Tahun 1977 tentang Perwakafan Tanah Milik yang disusul dengan Peraturan Menteri dalam Negeri Nomor 6 Tahun 1977 tentang cara pendaftaran tanah mengenai Perwakafan Tanah Milik. Terakhir pada tanggal 27 Oktober 2004 diterbitkan Undang-Undang Republik Indonesia Nomor 41 Tahun 2004 tentang Wakaf. ${ }^{23}$

Pengaturan lebih lanjut mengenai Perwakafan di Indonesia juga dapat ditemui dalam peraturan perundang-undangan terkait wakaf yang diberlakukan di Indonesia, antara lain:

1. Undang-Undang Pokok Agraria Nomor 5 Tahun 1960;

2. Peraturan Pemerintah Nomor 28 Tahun 1977 tentang Tata Cara Perwakafan Tanah Milik;

3. Peraturan Menteri Agama Nomor 1 Tahun 1978 tentang Perincian Terhadap PP Nomor 28 Tahun 1977 tentang Tata Cara Perwakafan Tanah Milik;

4. Intruksi Presiden Nomor 1 Tahun 1991 tentang Kompilasi Hukum Islam;

5. Undang-Undang Nomor 41 Tahun 2004 tentang Wakaf;

6. Peraturan Pemerintah Republik Indonesia Nomor 42 Tahun 2006 tentang Pelaksanaan UU Nomor 41 Tahun 2004 tentang Wakaf;

7. Peraturan Badan Wakaf Indonesia ${ }^{24}$;

8. Peraturan Menteri Agama Nomor 4 Tahun 2009 tentang Administrasi Pendaftaran Wakaf Uang;

9. Peraturan Menteri Agama Nomor 73 Tahun 2013 tentang Tata Cara Perwakafan Benda Tidak Bergerak dan Benda Bergerak Selain Uang.

Untuk menjamin kepastian hukum di Indonesia, pengaturan yang berlaku saat ini mengharuskan wakaf dilakukan secara lisan maupun tertulis di hadapan Pejabat Pembuat Akta Ikrar Wakaf (PPAIW), kemudian akan dibuatkan Akta Ikrar Wakaf (AIW), dilakukan pendaftarkan, dibuat sertifikasi, dan diumumkan kepada publik. Apabila benda wakaf berupa tanah milik, dengan mendasarkan AIW maka tanah tersebut didaftarkan dan diajukan perubahan sertifikat ke Badan Pertanahan Nasional (BPN) perubahan menjadi tanah wakaf

\footnotetext{
${ }^{22}$ Saifuddin Noorhadi, (2005), "Wakaf dalam Perspektif Hukum Agraria Nasional: Kajian Teoritis ke Arah Pengelolaan dan Pendayagunaan Tanah Wakaf Bersifat Produktif Komersial”, Disertasi, Malang: Program Pascasarjana Universitas Brawijaya.

${ }^{23}$ Herman Hermit, (2007). Cara Memperoleh Sertifikat Tanah Wakaf, Bandung: Penerbit Mandar Maju, hlm. 58 .

24 Dapat dilihat pada: Badan Wakaf Indonesia (BWI), (2011). Himpunan Peraturan Badan Wakaf Indonesia Cetakan Kedua, Jakarta: Badan Wakaf Indonesia, hlm. 1-139.
} 
atas nama Nazhir (pengelola wakaf). Hal ini disebutkan dalam Undang-Undang Republik Indonesia Nomor 41 tahun 2004 tentang Wakaf (UU Wakaf), dan Peraturan Pemerintah Republik Indonesia Nomor 42 tahun 2006 tentang Pelaksanaan Undang-Undang Republik Indonesia Nomor 41 tahun 2004 tentang Wakaf (Peraturan Pemerintah RI Nomor 42 Tahun 2006). ${ }^{25}$

Adanya Keputusan Menteri Agama (KMA) Nomor 517 Tahun 2001 tentang Penataan Organisasi Kantor Urusan Agama Kecamatan menegaskan bahwa KUA berkedudukan di wilayah kecamatan dan bertanggung jawab kepada Kepala Kantor Departemen Agama Kabupaten/Kota yang dikoordinasi oleh Kepala Seksi Urusan Agama Islam/BIMAS dan Kelembagaan Agama Islam serta di pimpin oleh seorang Kepala yang tugas pokoknya adalah melaksanakan sebagian tugas Kantor Departemen Agama Kabupaten/Kota di bidang Agama Islam dalam wilayah Kecamatan. Berdasarkan Keputusan tersebut, eksistensi KUA Kecamatan sebagai institusi Pemerintah dapat diakui keberadaannya, karena memiliki landasan hukum yang kuat serta merupakan bagian dari struktur pemerintahan di tingkat Kecamatan.

Seiring dengan perubahan yang terjadi di Indonesia saat ini, KMA Nomor 517 Tahun 2001 tersebut telah disesuaikan dan dibuatlah pengaturan lebih lanjut yaitu dalam Peraturan Menteri Agama Republik Indonesia Nomor 34 Tahun 2016 tentang Organisasi dan Tata Kerja Kantor Urusan Agama Kecamatan yang di dalamnya berisikan mengenai kedudukan, tugas dan fungsi Kantor Urusan Agama Kecamatan ${ }^{26}$, khususnya pada Pasal 3 poin (h) yaitu tentang Pelayanan Bimbingan Zakat dan Wakaf. Dengan adanya PMA ini, perkembangan wakaf di Indonesia $^{27}$ kini semakin meningkat seiring dengan meningkatnya pemahaman keagamaan masyarakat, sehingga menimbulkan tingginya kesadaran masyarakat akan pentingnya wakaf. Namun tingginya kesadaran masyarakat ini harus difasilitasi oleh negara sebagai pemegang regulasi perwakafan di Indonesia, dengan meningkatkan kualitas pelayanan di Kantor Urusan Agama (selanjutnya disebut dengan KUA) sebagai Pejabat Pembuat Akta Ikrar Wakaf (selanjutnya disebut dengan PPAIW) yang menjadi ujung tombak pelayanan administrasi wakaf bagi para calon wakif dan juga nazhir.

\footnotetext{
${ }^{25}$ Etika Rahmawati, (2020). Ibid, hlm. 52.

${ }^{26}$ Bisa dilihat lebih lanjut dalam Peraturan Menteri Agama Republik Indonesia Nomor 34 Tahun 2016 tentang Organisasi Dan Tata Kerja Kantor Urusan Agama Kecamatan.

27 M.E. Burhanuddin, (2020), Meningkatkan Peran dan Fungsi KUA sebagai Ujung Tombak Pengamanan Wakaf, https://www.bwi.go.id/5016/2020/06/24/meningkatkan-peran-dan-fungsi-kua-sebagaiujung-tombak-pengamanan-wakaf/, (diakses pada 09 Mei 2021).
} 
Jika dicermati kembali perkembangan yang terjadi di Indonesia, bisa dikatakan belum sejalan dengan fakta yang terjadi di lapangan karena masih banyak kasus-kasus perwakafan di Indonesia, seperti penyelewengan, persengketaan, penghilangan dan bahkan pelepasan harta benda wakaf bermula dari masalah tertib administrasi hukum. Betapa banyak harta benda wakaf (khususnya wakaf tanah) yang hilang atau lepas karena belum adanya Akta Ikrar Wakaf (AIW) atau sertifikat wakaf. KUA yang merupakan satuan unit terkecil dari birokrasi Kementerian Agama Republik Indonesia sebagai ujung tombak Kementerian Agama yang memiliki tugas pokok dan fungsi yaitu melaksanakan sebagian tugas Kantor Kementerian Agama Kabupaten/Kota di bidang urusan agama Islam dan membantu pembangunan pemerintahan umum di bidang agama di tingkat kecamatan. Fungsi yang dijalankan oleh KUA meliputi fungsi Administrasi, fungsi pelayanan, fungsi pembinaan, fungsi penerangan dang fungsi penyuluhan. KUA juga berperan sebagai koordinator pelaksanaan kegiatan pengawas Madrasah dan Pendidikan Agama Islam serta kegiatan Penyuluhan Agama Islam.

KUA merupakan instansi yang mempunyai peran cukup strategis dalam melakukan upaya pemberdayaan dan transformasi sosial. Oleh karena itu, KUA dituntut tidak hanya melaksanakan tugas-tugas formal saja, tetapi juga harus mampu menunjukkan ekstensinya sebagai sebuah instansi perpanjangan tangan Departemen Agama dalam melaksanakan pelayanan publik di bidang urusan agama Islam. KUA juga merupakan lembaga yang salah satu fungsinya sebagai pengelola wakaf berdasarkan Undang-Undang Wakaf, turut serta dalam mengelola hal perwakafan di tingkat Kecamatan. Pengelolaan dan pemberdayaan harta wakaf dilaksanakan oleh seseorang yang bertindak sebagai Nazhir (KUA), yang mana harta wakaf tersebut diawasi oleh KUA setempat. Selain sebagai Nazhir pengelolaan wakaf, KUA juga sebagai PPAIW (Pegawai Pencatat Akta Ikrar Wakaf) bagi Wakif yang berkeinginan mewakafkan hartanya. Peran KUA sebagai PPAIW dalam penyelenggaraan pendaftaran tanah wakaf berjalan sesuai dengan peraturan perundang-undangan.

\section{Implementasi Pembuatan Ikrar Wakaf di Kecamatan Rasau Jaya}

Pengelolaan wakaf di Kecamatan Rasau Jaya selama ini diatur berdasarkan UndangUndang Nomor 41 Tahun 2004 tentang Wakaf. Keberadaan Undang-Undang Wakaf sudah cukup komprehensif untuk mengatur tata kelola wakaf di Indonesia. Namun, dalam praktiknya, kewenangan untuk melakukan pembinaan dan pengawasan terhadap Nazhir, serta melakukan pemberdayaan harta wakaf menjadi kewenangan dari Badan Wakaf Indonesia 
(BWI) dan Kantor Urusan Agama (KUA) di bawah Kementerian Agama yang diamanatkan dalam Undang-Undang Wakaf.

Pembahasan mengenai perwakafan, sedikitnya terdapat 5 (lima) stakeholeders yang terkait baik dari awal proses pendaftaran sampai dengan dikeluarkannya akta ikrar wakaf. Yaitu: Wakif (orang yang mewakafkan); Nazhir (orang yang diberikan tugas untuk mengelola tanah wakaf); Dua orang saksi (orang yang menyaksikan ikrar wakaf); Pejabat Pembuat Akta Ikrar Wakaf (Biasa disebut dengan PPAIW) yang berasal dari dalam KUA; dan para petugas pendaftaran tanah yang ada di Kantor Pertanahan (Kabupaten/Kota).

Secara administratif, Kantor Urusan Agama (KUA) Kecamatan Rasau jaya terletak di Jalan Raya Rasau Jaya, Rasau Jaya Satu, Rasau Jaya, Kabupaten Kubu Raya, Kalimantan Barat. KUA Kecamatan Rasau Jaya dalam melaksanakan tugasnya, berusaha memberikan pelayanan yang baik kepada masyarakat yang ingin mewakafkan sebagian hartanya. Seperti yang kita ketahui, Ikrar wakaf akan terlaksana dengan baik apabila terpenuhi syarat dan rukunnya dan syarat-syarat wakaf juga harus dipenuhi. Setelah berkas yang diperlukan lengkap, maka akan dilangsungkan ikrar wakaf, dan akta ikrar wakaf akan langsung diberikan. Selanjutnya, Kepala KUA akan membuatkan pengantar untuk mengurus diterbitkannya sertifikat wakaf di kantor Badan Pertanahan Nasional (BPN) setempat.

Berdasarkan paparan secara umum di atas, Penulis melakukan wawancara di Kantor Urusan Agama $^{28}$ (KUA) Kecamatan Rasau Jaya mengenai prosedur pendaftaran akta ikrar wakaf di KUA Kecamatan Rasau Jaya. Berdasarkan hasil wawancara tersebut diketahui data tentang proses pendaftaran Akta Ikrar Wakaf di KUA Rasau Jaya dilaksanakan dengan beberapa persyaratan, antara lain:

Tabel 1. Persyaratan AIW di KUA Kecamatan Rasau Jaya

\begin{tabular}{|c|l|}
\hline No. & Persyaratan Akta Ikrar Wakaf \\
\hline 1. & Surat Tanah : SPT/Sertifikat; \\
\hline 2. & Fotocopy KTP Wakif; \\
\hline 3. & Fotocopy KTP Nadzir (5 Orang); \\
\hline 4. & Materai Rp. 10.000 sebanyak 12 Lembar; \\
\hline 5. & Ijab Qobul AIW Kepala KUA; \\
\hline 6. & Surat Keterangan Waris; \\
\hline 7. & $\begin{array}{l}\text { 3 Rangkap: } \\
\text { a) Wakif; } \\
\text { b) Nadzir; } \\
\text { c) KUA. }\end{array}$ \\
\hline
\end{tabular}

${ }^{28}$ Wawancara dengan Bapak Mukhsin, S.H.I. Kepala KUA Kecamatan Rasau Jaya, yang dilakukan pada tanggal 04 Agustus 2021, Jam 13.00 WIB. 


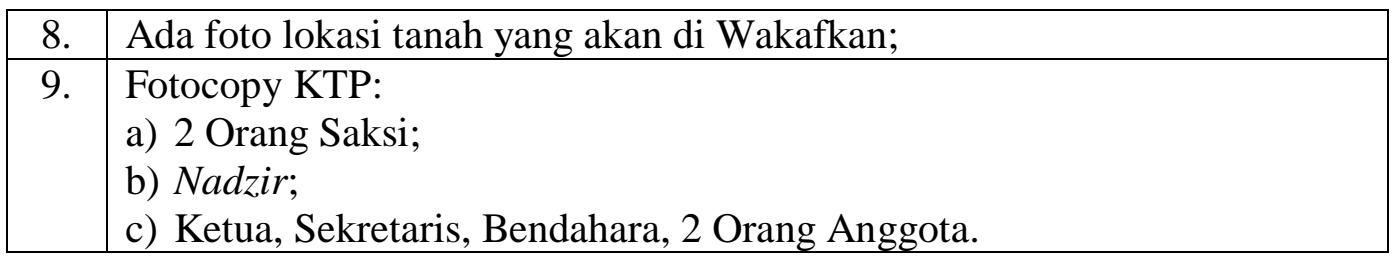

Sembilan syarat yang tertuang dalam persyaratan di atas merupakan syarat mutlak yang harus dipenuhi masyarakat yang akan mengajukan ikrar wakaf. Jika salah satu dari syarat tersebut tidak ada, maka Ikrar wakaf tidak akan terlaksana. Untuk selanjutnya, setelah persyaratan ini dipenuhi, ada beberapa tahapan sampai kepada didaftarkannya AIW ke Badan Pertanahan Nasional untuk ditingkatkan statusnya menjadi Sertifikat tanah wakaf. Adapun tahapannya dijabarkan dalam bentuk bagan di bawah ini:

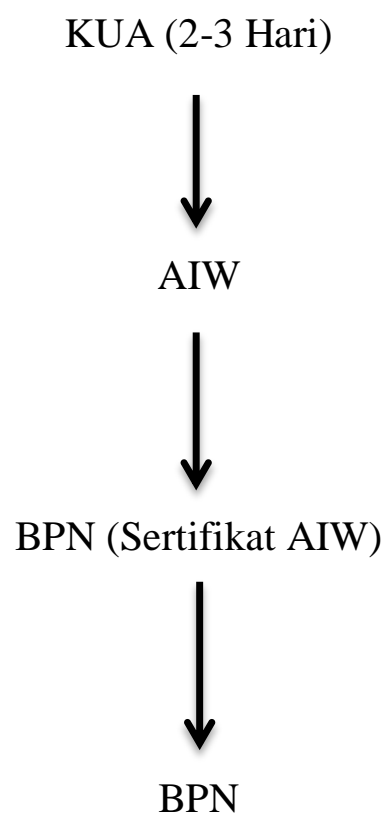

Bagan 1. AIW sampai ke tahap Pendaftaran Sertipikat Tanah Wakaf

Berdasarkan prosedur di atas, untuk membuat Akta Ikrar Wakaf di KUA Kecamatan Rasau Jaya, dibutuhkan waktu sekitar 2-3 hari untuk menyelesaikan berkas-berkas yang harus dilengkapi oleh masyarakat yang akan membuat akta ikrar wakafnya. Setelah pemberkasan terpenuhi dan dianggap lengkap, selanjutnya akan dijadwalkan oleh KUA Kecamatan Rasau Jaya untuk dilakukannya Akta Ikrar Wakaf di hadapan Pejabat Pembuat Akta Ikrar Wakaf (PPAIW). Ikrar Wakaf yang sudah terlaksana, selanjutnya akan dibuatkan dalam bentuk Akta yang nantinya akan dibawa ke BPN untuk didaftarkan haknya dan agar status akta tersebut dapat meningkat menjadi Sertifikat Tanah Wakaf. Mengenai waktu dalam tiap proses di atas 
tidak ada dicantumkan dan tidak dijelaskan lebih lanjut oleh pihak KUA Kecamatan Rasau Jaya pada saat dilakukan wawancara.

Wawancara dengan Pegawai bidang Perwakafan di KUA Kecamatan Rasau Jaya dilakukan dalam rangka mendapatkan data yang valid. Adapun data tersebut sebagai berikut:

Tabel 2. Daftar Ikrar Wakaf yang sudah terlaksana Tahun 2019

\section{DAFTAR IKRAR WAKAF TAHUN 2019}

\begin{tabular}{|c|c|c|c|c|c|c|}
\hline NO & NO. WAKAF & NAMA MASJID/SURAU & NAMA WAKIF/NADZIR & STATUS TANAH & LUAS & TANGGAL \\
\hline \multirow{2}{*}{1} & \multirow{2}{*}{ W2/01/I/2019 } & \multirow{2}{*}{ Surau Al-Hikmah R. Jaya Umum } & Wakif: Sudarman & AIW/SKT & $100 \mathrm{~m} 2$ & \multirow{2}{*}{17 Januari 2019} \\
\hline & & & Nadzir: Hamdi & Wakaf & P.10 L.10m & \\
\hline \multirow{2}{*}{2} & \multirow{2}{*}{ W2/02/I/2019 } & \multirow{2}{*}{ Surau Al-Barokah R. Jaya Umum } & Wakif: Rusli Marzuki & Wakaf & $229,5 \mathrm{~m} 2$ & \multirow{2}{*}{17 Januari 2019} \\
\hline & & & Nadzir: Kholis & AIW/SKT & P.17 L. $13,5 \mathrm{~m}$ & \\
\hline \multirow{2}{*}{3} & \multirow{2}{*}{ W2/03/I/2019 } & Pengembangan Persyarikatan & Wakif: Mujiono & Wakaf & $720 \mathrm{~m} 2$ & \multirow{2}{*}{22 Januari 2019} \\
\hline & & Muhadiyah R. Jaya Satu & Nadzir: Miftahul Huda & AIW/Sertifikat & P.40 L. $18 \mathrm{~m}$ & \\
\hline \multirow{2}{*}{4} & \multirow{2}{*}{ W2/04/I/2019 } & \multirow{2}{*}{ Muhammadiyah R. Jaya Tiga } & Wakif: Yatmi & Wakaf & $10.000 \mathrm{~m} 2$ & \multirow{2}{*}{28 Januari 2019} \\
\hline & & & Nadzir: Miftahul Huda & AIW/Sertifikat & P.100 L. $100 \mathrm{~m}$ & \\
\hline \multirow{2}{*}{5} & \multirow{2}{*}{ W2/05/I/2019 } & \multirow{2}{*}{ Surau Nur Hidayah R. Jaya Satu } & Wakif: Gandung Suroso & Wakaf & $200 \mathrm{~m} 2$ & \multirow{2}{*}{28 Januari 2019} \\
\hline & & & Nadzir: Jumari & AIW/SPT & P.100 L.20m & \\
\hline \multirow{2}{*}{6} & \multirow{2}{*}{ W2/06/I/2019 } & \multirow{2}{*}{ Surau Al Amin R. Jaya Tiga } & Wakif: Berima & Wakaf & $300 \mathrm{~m} 2$ & \multirow{2}{*}{24 Januari 2019} \\
\hline & & & Nadzir: Rusli & AIW/SPT & P.25 L. $12 \mathrm{~m}$ & \\
\hline \multirow{2}{*}{7} & \multirow{2}{*}{ W2/07/I/2019 } & Masjid Miftahul Jannah & Wakif: Kamaludin & Wakaf & $1.200 \mathrm{~m} 2$ & 31 Januari 2019 \\
\hline & & R. Jaya Umum & Nadzir: Yakop & AIW/Sertifikat & P.40 L. $30 \mathrm{~m}$ & ग1 Janluan 2019 \\
\hline 8 & $\mathrm{~W} 2 / 08 / \mathrm{J} / 2019$ & Pekuburan Muslim Miftahul & Wakif: Kamaludin & Wakaf & $5.650 \mathrm{~m} 2$ & \\
\hline$\gamma$ & W $2 / 08 / 1 / 2019$ & Jannah I R. Jaya Umum & Nadzir: Yakop & AIW/SPT & P.113 L.50m & 31 Januarı 2019 \\
\hline 9 & $\mathrm{~W} 2 / 09 / \mathrm{J} / 2019$ & Pekuburan Muslim Miftahul & Wakif: Kamaludin & Wakaf & $3.500 \mathrm{~m} 2$ & 31 Januari 2019 \\
\hline 9 & W $2 / 0911 / 2019$ & Jannah 2 R. Jaya Umum & Nadzir: Yakop & AIW/SPT & P.70 L.50m & ग1 Jalluall 2019 \\
\hline 10 & W2/10/II/2019 & Surau Nur Iman R Java Satu & Wakif: Eni Wijayati & Wakaf & $313 \mathrm{~m} 2$ & 04 Februari 2019 \\
\hline 10 & W2/10/11/2019 & surau Nur Iman K. Jaya satu & Nadzir: Juwono, SP & AIW/Sertifikat & P. 22 L. $15 \mathrm{~m}$ & 04 Feoruarl 2019 \\
\hline 11 & W2/11/ா/2019 & Masjid DH Babul Khoir & Wakif: H.M. Muchotib & Wakaf & $600 \mathrm{~m} 2$ & 04 Fehruari 2019 \\
\hline 11 & $\mathrm{~W} 2 / 11 / 11 / 2019$ & R. Jaya Satu & Nadzir: Tosim Sutikno & AIW/SPT & P.30 L.20m & O4 reviuan 2019 \\
\hline 12 & W2/12/II/2019 & Surau Nurul Hidayah & Wakif: Nurhasan & Wakaf & $1.100 \mathrm{~m} 2$ & 11 Maret 2019 \\
\hline 12 & W2/12/11/2019 & R. Jaya Umum & Nadzir: Ahmad Sun & AIW/SPT & P.10 L. $10 \mathrm{~m}$ & 11 Maret 2019 \\
\hline 13 & W2/13/II/2019 & Masjid Bubus Sholihin & Wakif: Munakif & Wakaf & $10.125 \mathrm{~m} 2$ & 26 Maret 2019 \\
\hline 10 & WL/15/W/2019 & R. Jaya Umum & NadzirHasan Basri & AIW/SPT & P.135 L.75m & 20 Mratel 2019 \\
\hline 14 & W2/14/IV/2019 & Masjid Nurul Ihsan & Wakif: Sri Nardi & Wakaf & $15.100 \mathrm{~m} 2$ & 15Anril 2019 \\
\hline 14 & W2/14/1V/2019 & R. Jaya Dua & Nadzir: Sugianto & AIW/SPT & P.180 L. $90 \mathrm{~m}$ & 1Ј Арम1 2019 \\
\hline 15 & $\mathrm{~W} 2 / 15 / \mathrm{Vt} / 2019$ & Surau Nahdhotus Sholihin & Wakif: Yatmoko & Wakaf & $423 \mathrm{~m} 2$ & 15 Juli 2019 \\
\hline 13 & WL/1J/VII/2U19 & R. Jaya Satu & Nadzir: Muhammad Sholihin & AIW/SPT & P.42,3 L. $10 \mathrm{~m}$ & 15 गuाl 2019 \\
\hline 16 & W2/16/IX/2019 & Masjid Nurul Hidayah & Wakif: Mattali & Wakaf & $741 \mathrm{~m} 2$ & 03 Sentember 2019 \\
\hline & & R. Jaya Satu & Nadzir: Taryono & AIW/SPT & P.19 L.39m & \\
\hline 17 & W2/17/X/2019 & Wakaf Kuburan Muslim & Wakif: Suparno & Wakaf & $27330 \mathrm{~m}$ & 09 Oktoher \\
\hline 11 & WL/1//N/2019 & Patok 20 R. Jaya Satu & Nadzir: H. Ngatryat & AIW/Sertifikat & $27.530 \mathrm{~mL}$ & 09 UKtoder 2019 \\
\hline 18 & W2/18/X/2019 & Masiid Al-Mu'min R Java Umum & Wakif: Is Dahlia & Wakaf & $900 \mathrm{~m} 2$ & 09 Oktoher 2019 \\
\hline 10 & WLIIO/N/LUTS & 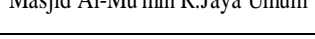 & Nadzir: Hasanudin & AIW/SPT & P. 30 L. $30 \mathrm{~m}$ & 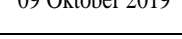 \\
\hline 19 & W2/19/X/2019 & Wakaf Tanah Kuburan & Wakif: Sumarni & Wakaf & & \\
\hline 19 & W2/191X/2019 & Patok 18 R. Jaya Satu & Nadzir: H. Ngatryat & AIW/SPT & $21.330 \mathrm{~m} 2$ & 09 Uktober 2019 \\
\hline 20 & W2/20/XI/2019 & Masjid Jami' Al Hidayah & Wakif: Syamsuddin & Wakaf & $3.600 \mathrm{~m} 2$ & 07 Nonember 2019 \\
\hline 20 & WLIZU/XI/2019 & R. Jaya Dua & Nadzir: Abdul Malik & AIW/SPT & P. 90 L. $40 \mathrm{~m}$ & $0 /$ Nopember 2019 \\
\hline
\end{tabular}

Tahun 2018, KUA Kecamatan rasau jaya telah mendata sebanyak 35 kasus tanah wakaf yang belum didaftarkan ke KUA Kecamatan Rasau Jaya untuk ditingkatkan menjadi Akta Ikrar Wakaf. KUA bersama dengan pemerintahan desa bekerja sama melalui penyuluh yang kompeten untuk memberikan penyuluhan terkait perwakafan kepada masyarakat setempat. Karena, mengingat karektiristik atau mayoritas dari masyarakat di Kecamatan 
Rasau Jaya bekerja sebagai petani, kemudian mereka beranggapan bahwa tanah wakaf hanya bersifat ibadah saja dengan niat yang ikhlas dan tidak memandang pentingnya akta ikrar wakaf dan konsekuensi apa yang ditimbulkan kedepannya apabila tanah wakaf tersebut tidak ditingkatkan status kepemilikannya. Pada tahun 2018 juga, ada kegiatan Penyuluhan dan Sosialisasi Hukum yang dilakukan oleh Dosen STIS Syarif Abdurrahman Pontianak dengan melibatkan beberapa Instansi terkait yaitu KUA Kecamatan Rasau Jaya dan Badan Pertanahan Nasional (BPN/ATR) Kabupaten Kubu Raya serta menghadirkan narasumber yang berkompeten dan masyarakat yang memiliki tanah wakaf. Pada saat itu, dilakukan komunikasi 2 (dua) arah antara masyarakat dan narasumber yang dihadirkan guna membahas permasalahan terkait proses pendaftaran Akta Ikrar Wakaf sampai tahapan akhir pendaftaran Hak untuk ditingkatkan statusnya menjadi sertipikat tanah wakaf.

Melalui kegiatan penyuluhan hukum perwakafan tersebut, dari total 35 (tiga puluh lima) kasus tanah wakaf yang terdaftar, pada tahun 2019 KUA Kecamatan Rasau Jaya menerima 20 (dua puluh) pendaftar yang memiliki tanah wakaf dan ingin meningkatkan status kepemilikannya dengan membuat Akta Ikrar Wakaf. Sehingga pada tahun 2019 capaian KUA Kecamatan Rasau Jaya terhadap pembuatan Akta Ikrar Wakaf sebanyak 57\% (lima puluh tujuh persen).

\section{Tabel 3. Daftar Ikrar Wakaf yang sudah terlaksana Tahun 2020}

DAFTAR IKRAR WAKAF TAHUN 2020

\begin{tabular}{|c|c|c|c|c|c|c|}
\hline NO & NO. WAKAF & NAMA MASJID/SURAU & NAMA WAKIF/NADZIR & STATUS TANAH & LUAS & TANGGAL \\
\hline \multirow{2}{*}{1} & \multirow{2}{*}{ W2/01///2020 } & Surau Firdaus Muslim & Wakif: H. Subandi & \multirow{2}{*}{ SPT/SKT } & $600 \mathrm{~m} 2$ & \multirow{2}{*}{22 Januari 2020} \\
\hline & & R. Jaya Satu & Nadzir: Saridi & & P. 40 L. $15 \mathrm{~m}$ & \\
\hline \multirow{2}{*}{2} & \multirow{2}{*}{$\mathrm{W} 2 / 02 / \mathrm{V} / 2020$} & \multirow{2}{*}{ Surau Nurul Hupa R. Jaya Satu } & Wakif: Kastubi & Sertifikat & \multirow{2}{*}{$644 \mathrm{~m} 2$} & \multirow{2}{*}{04 Mei 2020} \\
\hline & & & Nadzir: Bambang Sutrisno & HM No. 05705 22-11-2019 & & \\
\hline \multirow{2}{*}{3} & \multirow{2}{*}{$\mathrm{W} 2 / 03 / \mathrm{VI} / 2020$} & \multirow{2}{*}{ Masjid Thoriqul Jannah } & Wakif: Bambang Sutrisno & Sertifikat & \multirow{2}{*}{$9.754 \mathrm{~m} 2$} & \multirow{2}{*}{15 Juni 2020} \\
\hline & & & Nadzir: Tami & HM No. 04489 14-04-2020 & & \\
\hline \multirow{2}{*}{4} & \multirow{2}{*}{ W2/04/VII/2020 } & Surau Bahrul Hidayah & Wakif: Sodikin & SPT. 593/072/III/Pem 2020 & $627 \mathrm{~m} 2$ & \multirow{2}{*}{10 Maret 2020} \\
\hline & & R. Jaya Satu Patok 6 & Nadzir: Riyanto & 10 Maret 2020 & P. 33 L. $19 \mathrm{~m}$ & \\
\hline \multirow{2}{*}{5} & \multirow{2}{*}{ W2/05/VIII/2020 } & Masjid DH Babul Khoir & Wakif: H.M. Muchotib & SPT.593/087/VI/Pem 2020 & $990 \mathrm{~m} 2$ & \multirow{2}{*}{03 Agustus 2020} \\
\hline & & Patok 5 R. Jaya Satu & Nadzir: Tosim Sutirno & 03 Juni 2020 & P. 45 L. $22 \mathrm{~m}$ & \\
\hline \multirow[b]{2}{*}{6} & \multirow{2}{*}{$\mathrm{W} 2 / 06 / \mathrm{X} / 2020$} & Yayasan Arrahman & Wakif: Artum & SPT.593/768/IX/Pem 2020 & $525 \mathrm{~m} 2$ & \multirow{2}{*}{08 Oktober 2020} \\
\hline & & Abdullah bin Halik & Nadzir: Bakhtiar & 30 September 2020 & P. 50 L. $10,5 \mathrm{~m}$ & \\
\hline \multirow{2}{*}{7} & \multirow{2}{*}{$\mathrm{W} 2 / 07 / \mathrm{X} / 2020$} & Yayasan Arrahman & Wakif: Ariffa & SPT.593/768/IX/Pem 2020 & $525 \mathrm{~m} 2$ & \multirow{2}{*}{08 Oktober 2020} \\
\hline & & Abdullah bin Halik & Nadzir: Bakhtiar & 30 September 2020 & P.50 L. $10,5 \mathrm{~m}$ & \\
\hline \multirow{2}{*}{8} & \multirow{2}{*}{ W2/08/XI/2020 } & \multirow{2}{*}{ Yayasan Baitul Jannah } & Wakif: Barkuh & SPT.593/1154/IX/Pem 2020 & $10.000 \mathrm{~m} 2$ & \multirow{2}{*}{05 Nopember 2020} \\
\hline & & & Nadzir: Jumadi & 03 Sptember 2020 & P. 400 L. $25 \mathrm{~m}$ & \\
\hline \multirow{2}{*}{9} & \multirow{2}{*}{ W2/09/XII/2020 } & \multirow{2}{*}{ Makam Muslim Darussalam } & Wakif: Srameh & \multirow{2}{*}{ Sertifikat 4519} & \multirow{2}{*}{$17.943 \mathrm{~m} 2$} & \multirow{2}{*}{03 Desember 2020} \\
\hline & & & Nadzir: Suyanto & & & \\
\hline
\end{tabular}

Pada tahun 2020, KUA Kecamatan Rasau Jaya masih mengutamakan capaian ditahun sebelumnya. Dari 35 (tiga puluh lima) kasus sudah direalisasikan sebanyak 20 Akta ikrar wakaf (57\%) di tahun 2019, sehingga masih ada 15 kasus tanah wakaf yang perlu diproses hak atas tanah wakaf untuk mendapatkan akta ikrar wakafnya. Pada tahun 2020, ada 9 
(sembilan) pendaftar hak atas tanah wakaf yang akan ditingkatkan status kepemilikan tanah wakafnya dengan mendapatkan Akta Ikrar Wakaf. Sehingga capaian yang didapat pada tahun 2019-2020 sebanyak 83\% (delapan puluh tiga persen).

\section{Tabel 4. Daftar Ikrar Wakaf yang sudah terlaksana Tahun 2021}

\section{DAFTAR IKRAR WAKAF TAHUN 2021}

\begin{tabular}{|c|c|c|c|c|c|c|}
\hline NO & NO. WAKAF & NAMA MASJID/SURAU & NAMA WAKIF/NADZIR & STATUS TANAH & LUAS & TANGGAL \\
\hline 1 & W2/01/III/2021 & Pemakaman Umum & Wakif: H. Maksum & SPT. 593/492/XI/Pem 2021 & $9.375 \mathrm{~m} 2$ & $05 \mathrm{Maret} 2021$ \\
\hline 2 & \multirow{2}{*}{ W2/02/V/2021 } & Pemakamanam Umum & Wakif: Muhammad Yadi & SHM. 7985 & P.125 L.75m & $5.960 \mathrm{~m} 2$ \\
\hline
\end{tabular}

Pada tahun 2021 sampai pada bulan Agustus, berdasarkan data yang didapat, KUA Kecamatan Rasau Jaya mencatat 2 (dua) pendaftar tanah wakaf yang sedang diajukan untuk diikrarkan. Artinya, dari total 35 kasus di tahun 2019, sampai dengan tahun 2021 sudah ada 31 (tiga puluh satu) kasus yang diproses akta ikrar wakafnya sehingga capaian yang didapat sebanyak $86 \%$ (delapan puluh enam persen). Untuk tahun 2022, masih ada 4 (empat) kasus yang belum terealisasi atau belum tercapai pelaksanaan ikrar wakaf, jika dipersentase maka masih tersisa $14 \%$ (empat belas persen).

Masyarakat yang pada awalnya hanya memandang wakaf bersifat ibadah dengan niat yang ikhlas saja, sehingga tidak melihat konsekuensi hukum apa yang akan didapat ketika tanah wakaf ini tidak ditingkatkan pada proses pendaftaran akta ikrar wakaf ke KUA setempat. Berdasarkan data di atas, antusiasme masyarakat dalam mendaftarkan tanah wakaf untuk mendapatkan kepastian hukum cukup banyak. Dari data 3 (tiga) tahun terakhir diketahui banyak pendaftar yang memproses tanah wakafnya untuk mendapatkan Akta Ikrar Wakaf. Adanya upaya KUA Kecamatan Rasau Jaya yang melibatkan pemerintahan desa dalam kegiatan penyuluhan perwakafan perlahan memunculkan kesadaran masyarakat dalam pendaftaran akta ikrar wakaf bagi tanah wakaf yang dimiliki masyarakat setempat. Keterbatasan pengetahuan masyarakat di sana yang mayoritasnya bekerja sebagai petani membuat mereka enggan untuk meningkatkan proses tanah wakaf mereka. Dengan adanya kegiatan penyuluhan tersebut, masyarakat dapat memahami prosedur pendaftaran akta ikrar wakaf sampai akhir mendapatkan Akta Ikrar wakaf. Walaupun Akta Ikrar Wakaf ini belum menjamin sepenuhnya, karena akta ikrar wakaf yang sudah jadi nantinya diarsipkan dalam bentuk dokumen yang disimpan di KUA, BWI dan Pengadilan Agama (sebagai bentuk tanggungjawab pemerintah). Tetapi sudah menjadi langkah awal yang baik untuk meningkatkan hak atas tanah wakaf yang mereka miliki. KUA dalam hal ini juga membantu 
masyarakat yang akan mendaftarkan tanah wakafnya untuk mendapatkan sertipikat hak atas tanah wakaf di Badan Pertanahan Nasional dengan rekomendasi dari Pengadilan Agama setempat.

Kantor Urusan Agama (KUA) memiliki peranan yang sangat penting dalam prosedur wakaf. Kepala KUA sebagai Pejabat Pembuat Akta Ikrar Wakaf (PPAIW) dituntut cermat dalam meneliti dokumen-dokumen yang terkait dengan tanah atau harta benda yang akan diwakafkan, memenuhi syarat untuk diwakafkan atau tidak. Peran PPAIW juga meneliti saksi-saksi dan melakukan pengesahan Nazhir (pengelola harta wakaf). Hal ini agar kedepannya proses sertifikasi tanah atau harta benda yang diwakafkan tidak terkendala. Semakin tingginya kesadaran masyarakat untuk mewakafkan harta bendanya, hal ini menuntut KUA untuk memberikan pelayanan administrasi yang prima, baik itu kepada calon Wakif (orang yang mewakafkan) maupun Nazhir.

Berdasarkan wawancara dan data yang didapat pada saat di lapangan (bisa dilihat pada pembahasan sebelumnya), fungsi sosialisasi hukum wakaf yang ada di KUA Kecamatan Rasau Jaya dikatakan belum efektif. Secara administrasi, alur pendaftaran (seperti yang pada pembahasan sub di atas) masih dinilai belum baik. Kejelasan akan alur dalam administrasi pada proses pendaftaran Ikrar wakaf seharusnya lebih diperhatikan. Adapun alur proses pendaftaran sampai penerbitan Akta Ikrar Wakaf melalui bagan di bawah ini:

Bagan 2. Alur proses pendaftaran sampai penerbitan Akta Ikrar Wakaf.

\begin{tabular}{|c|c|c|}
\hline INPUT & PROSES & OUTPUT \\
\hline $\begin{array}{l}\text { Persyaratan seperti: } \\
\text { - Sertipikat Hak Milik; } \\
\text { - Surat Persetujuan Ahli } \\
\text { Waris; } \\
\text { - Surat Keterangan } \\
\text { Kepala Desa diperkuat } \\
\text { oleh camat setempat; } \\
\text { - Dan lain-lain. }\end{array}$ & $\begin{array}{l}\text { - Wakif datang ke Nadzir dengan } \\
\text { membawa surat-surat; } \\
\text { - Nadzir dan wakif mendatangi } \\
\text { KUA untuk melaksanakan ikrar } \\
\text { wakaf dan melengkapi } \\
\text { persyaratan; } \\
\text { - KUA, diwakili oleh PPAIW } \\
\text { menerima wakif dan Nadzir } \\
\text { serta surat-surat kelengkapan } \\
\text { dan memeriksa kebenarannya; } \\
\text { - Pelaksanaan Ikrar wakaf } \\
\text { (Tertera waktu pelaksanaan } \\
\text { dalam berapa hari). }\end{array}$ & $\begin{array}{l}\text { - AKTA IKRAR } \\
\text { WAKAF }\end{array}$ \\
\hline
\end{tabular}

Berdasarkan bagan tersebut di atas, setidaknya dapat memberikan informasi kepada masyarakat pada saat awal datang untuk mengurus administrasi perwakafan di KUA Kecamatan Rasau Jaya, tentunya juga diikuti dengan sosialisasi hukum perwakafan oleh KUA 
setempat. Ketidakjelasan dalam informasi dan kurangnya sosialisasi hukum perwakafan kepada masyarakat dalam kurun waktu 3 (tiga) tahun ini, menjadikan tingkat kesadaran masyarakat akan pentingnya hukum wakaf dianggap kurang. Hasil dari wawancara yang dilakukan, diketahui bahwa sosialisasi hukum terkait dengan prosedur tanah wakaf baru dilaksanakan sekali dan sosialisasi tersebut terlaksana karena partisipasi instansi pendidikan yang melibatkan banyak pihak dan narasumber yang berkompeten. Menjadi hal yang wajar ${ }^{29}$ ketika tahun 2019 data ikrar wakaf yang sudah terealisasi naik menjadi 20 (dua puluh) tanah wakaf, karena diimbangi dengan sosialisasi dan pendampingan pembuatan akta ikrar wakaf.

Masyarakat yang sadar dan patuh terhadap hukum dapat tercipta dari kegiatan sosialisasi hukum yang dilakukan secara terus menerus ${ }^{30}$. Hal ini penting dalam rangka mencapai kepatuhan hukum di mana diperlukan usaha terus menerus untuk memasyarakatkan hukum. Seperti fakta yang ditemukan di lapangan, tidak semua masyarakat di Kecamatan Rasau Jaya dengan sendirinya mengetahui tentang hukum. Karena mayoritas masyarakat setempat bekerja sebagai petani. Maka dari itu, perlu dilakukan berbagai cara untuk menyebarluaskan pengetahuan hukum khususnya dibidang perwakafan ini. KUA Kecamatan Rasau Jaya memiliki program penyuluhan perwakafan yang bekerja sama dengan pemerintahan desa guna penyuluhan sampai ke tingkat desa.

Menurut Lawrence M. Friedman ${ }^{31}$, dalam setiap sistem hukum terdiri dari 3 (tiga) sub sistem, yaitu sub sistem substansi hukum (legal substance), sub sistem struktur hukum (legal structure), dan subsistem budaya hukum (legal culture). Substansi hukum meliputi materi hukum yang diantaranya dituangkan dalam peraturan perundang-undangan. Struktur hukum menyangkut kelembagaan (institusi) pelaksana hukum, kewenangan lembaga dan personil (aparat penegak hukum). Sedangkan kultur hukum menyangkut perilaku (hukum) masyarakat. Ketiga unsur itulah yang mempengaruhi keberhasilan penegakan hukum di suatu masyarakat (negara), yang antara satu dengan lainnya saling bersinergi untuk mencapai tujuan penegakan hukum itu sendiri yakni keadilan.

${ }^{29}$ Wawancara Dosen STIS Syarif Abdurrahman Pontianak Pada tanggal 06 Agustus 2021, jam 10.00 WIB (Ibu Etika Rahmawati, S.H., M.Kn) yang melaksanakan pengabdian kepada masyarakat tentang Pendampingan Pembuatan Akta Ikrar Wakaf di Kecamatan Rasau Jaya, Kabupaten Kubu Raya, Kalimantan Barat.

${ }^{30}$ Muhammad Zulfikar dan Tasrief Tarmizi , Antara News, Artikel Yasonna: Masyarakat Sadar Hukum dapat Tercipta dari Sosialisasi Hukum, https://www.antaranews.com/berita/2096382/yasonna-masyarakatsadar-hukum-dapat-tercipta-dari-sosialisasi (diakses pada 16 Agustus 2021, jam 14.00 WIB).

${ }^{31}$ Lawrence M. Friedman, (2001). Hukum Amerika: Sebuah Pengantar, Terjemahan dari American Law An Introduction, 2nd Edition, Alih Bahasa: Wisnu Basuki, Jakarta: Tatanusa, hlm. 6-8. 
Penulis dalam hal ini menggunakan Teori Kultur Hukum dari Lawrence M. Friedman yang menyatakan bahwa kultur hukum atau budaya hukum bisa diartikan sebagai pola pengetahuan, sikap dan perilaku sekelompok masyarakat terhadap sebuah sistem hukum. Dari pola-pola tersebut dapat dilihat tingkat integrasi masyarakat tersebut dengan sistem hukum terkait. Secara mudah, tingkat integrasi ini ditandai dengan tingkat pengetahuan, penerimaan, kepercayaan dan kebergantungan mereka terhadap sistem hukum itu ${ }^{32}$.

Budaya hukum adalah sikap mental yang menentukan bagaimana hukum digunakan, dihindari, atau bahkan disalahgunakan. Struktur hukum yang tidak mampu menggerakkan sistem hukum akan menciptakan ketidakpatuhan (disobedience) terhadap hukum. Dengan demikian struktur hukum yang menyalahgunakan hukum akan melahirkan budaya menelikung dan menyalahgunakan hukum. Berjalannya struktur hukum sangat bergantung pada pelaksananya yaitu aparatur penegak hukum. Berdasarkan pada teori ini maka dapat dilihat bahwa pola pengetahuan, sikap dan perilaku sekelompok masyarakat terhadap pemahaman akan pentingnya Akta Ikrar Wakaf. Ketika sosialisasi hukum terkait perwakafan dilaksanakan, maka akan muncul kesadaran dalam masyarakat akan pentingnya kepastian hukum terhadap harta yang diwakafkannya. Namun, akan berbanding terbalik jika sosialisasi hukum perwakafan tidak dilaksanakan oleh KUA setempat dalam kurun waktu lama.

Peran dari KUA hanya sampai pada pembuatan AIW dan mengurus kelengkapan administrasi saja. PPAIW ${ }^{33}$ (yang biasanya dirangkap-jabatan oleh Kepala KUA) diwajibkan oleh "aturan main" resmi untuk bersegera mendaftarkan tanah tersebut ke Kantor Pertanahan (BPN) guna diterbitkan sertifikat wakaf oleh kantor pertanahan. Tenggat waktu yang diberikan aturan ${ }^{34}$ kepada PPAIW untuk bersegera tersebut adalah 3 (tiga) bulan setelah terbitnya Akta Ikrar Wakaf dari KUA. Dari hasil pengamatan di lapangan, Akta ikrar Wakaf yang sudah dikeluarkan tidak langsung diproses pendaftarannya ke Kantor Pertanahan. Karena, tergantung pada wakif dan nadzir mau memprosesnya lebih lanjut atau tidak. Secara umum, Nadzir dan wakif juga turut serta mendampingi PPAIW dalam mengurus permohonan pendaftaran tanah dan penerbitan sertipikat wakaf ke Kantor Pertanahan (BPN). Harta benda wakaf yang berupa tanah harus didaftarkan pada Badan Pertanahan untuk memperoleh kepastian dan memperoleh manfaat yang maksimal.

\footnotetext{
${ }^{32}$ Lawrence M. Friedman, (1975), The Legal System: A Social Science Prespective, New York: Russel Foundation.

${ }^{33}$ Herman Hermit, (2007), Cara Memperoleh Sertifikat Tanah Wakaf, Bandung: Penerbit Mandar Maju, hlm. 35 .

${ }^{34}$ Lihat Peraturan Menteri Dalam Negeri (Permendagri) Nomor 6 Tahun 1977 tentang Tata Cara Pendaftaran Tanah Mengenai Perwakafan Tanah Milik.
} 


\section{PENUTUP}

Dalam ketentuan umum Undang-Undang Wakaf, Pejabat Pembuat Akta Ikrar Wakaf (PPAIW) adalah pejabat berwenang yang ditetapkan oleh Menteri Agama Republik Indonesia untuk membuat Akta Ikrar Wakaf (AIW), yang dimaksud dengan pejabat disini adalah orang yang diberikan tugas dan kewenangan yang sah menurut hukum untuk membuat AIW. Sedangkan AIW adalah bukti pernyataan kehendak wakif untuk mewakafkan harta benda miliknya guna dikelola oleh Nazhir sesuai dengan peruntukan harta benda wakaf yang dituangkan dalam "Akta". Peran dan fungsi KUA sebagai ujung tombak pengamanan wakaf sangatlah penting, oleh karena itu diperlukan peningkatan kompetensi bagi pejabat pembuat akta ikrar wakaf baik dari sisi administrasi, pelayanan dan juga hukum wakaf. Kementerian Agama bersama Badan Wakaf Indonesia mempunyai peran penting dalam mengembangkan perwakafan di Indonesia bukan hanya dalam hal pembinaan Nazhir tetapi dalam meningkatkan kompetensi pejabat pembuat akta ikrar wakaf. Semoga dengan adanya karya ilmiah ini dapat menjadi sarana perbaikan dalam hal pendaftaran akta ikrar wakaf di lingkungan KUA Kecamatan Rasau Jaya.

Masyarakat yang pada awalnya hanya memandang wakaf bersifat ibadah dengan niat yang ikhlas saja, sehingga tidak melihat konsekuensi hukum apa yang akan didapat ketika tanah wakaf ini tidak ditingkatkan pada proses pendaftaran akta ikrar wakaf ke KUA setempat. Berdasarkan data di atas, antusiasme masyarakat dalam mendaftarkan tanah wakaf untuk mendapatkan kepastian hukum cukup banyak. Dari data 3 (tiga) tahun terakhir diketahui banyak pendaftar yang memproses tanah wakafnya untuk mendapatkan Akta Ikrar Wakaf. Adanya upaya KUA Kecamatan Rasau Jaya yang melibatkan pemerintahan desa dalam kegiatan penyuluhan perwakafan perlahan memunculkan kesadaran masyarakat dalam pendaftaran akta ikrar wakaf bagi tanah wakaf yang dimiliki masyarakat setempat. Keterbatasan pengetahuan masyarakat di sana yang mayoritasnya bekerja sebagai petani membuat mereka enggan untuk meningkatkan proses tanah wakaf mereka. Dengan adanya kegiatan penyuluhan tersebut, masyarakat dapat memahami prosedur pendaftaran akta ikrar wakaf sampai akhir mendapatkan Akta Ikrar Wakaf. Walaupun Akta Ikrar Wakaf ini belum menjamin sepenuhnya, karena akta ikrar wakaf yang sudah jadi nantinya diarsipkan dalam bentuk dokumen yang disimpan di KUA, BWI dan Pengadilan Agama (sebagai bentuk tanggungjawab pemerintah). Tetapi sudah menjadi langkah awal yang baik untuk meningkatkan hak atas tanah wakaf yang mereka miliki. KUA dalam hal ini juga membantu masyarakat yang akan mendaftarkan tanah wakafnya untuk mendapatkan sertifikat hak atas 
tanah wakaf di Badan Pertanahan Nasional dengan rekomendasi dari Pengadilan Agama setempat. 


\section{DAFTAR PUSTAKA}

\section{Buku}

Bambang Waluyo, (2002), Penelitian Hukum dalam Praktek, Jakarta: Sinar Grafika.

Cholid Narbuko dan Abu Achmadi, (2003), Metodologi Penelitian, Jakarta: PT. Bumi Aksara.

Herman Hermit, (2007). Cara Memperoleh Sertifikat Tanah Wakaf, Bandung: Penerbit Mandar Maju.

Lawrence M. Friedman, (1975), The Legal System: A Social Science Prespective, Russel Foundation, New York.

, (2001), Hukum Amerika: Sebuah Pengantar, Terjemahan dari American Law An Introduction, 2nd Edition, Alih Bahasa: Wisnu Basuki, Jakarta: Tatanusa.

Michael Quinn Patton, (1987), Triangulasi dalam Moleong (Ed.). Metode Penelitian Kualitatif Edisi Revisi, Cetakan ke-29. Bandung: PT. Remaja Rosdakarya.

Mochlasin, (2014), Manajemen Zakat dan Wakaf di Indonesia, Salatiga: STAIN Salatiga Press.

Mochtar Daniel, (2002), Metode Penelitian Sosial, Jakarta: Bumiaksara.

Robert K. Yin, (1998 \& 2009), Studi Kasus: Desain dan Metode, Terjemahan, Jakarta: PT. Grafindo Persada.

Snouck Hungronje, (1992), Nasihat-nasihat C. Hungronje Semasa Kepegawaiannya kepada Pemerintah Hindia Belanda 1889-1936, Jakarta: INIS.

Suharsimi Arikunto, (2010), Prosedur Penelitian Suatu Pendekatan Praktik, Jakarta: Rineka Cipta.

\section{Peraturan Perundang-Undangan}

Undang-Undang Nomor 41 Tahun 2004 tentang Wakaf.

Peraturan Pemerintah Republik Indonesia Nomor 42 Tahun 2006 tentang Pelaksanaan Undang-Undang Nomor 41 Tahun 2004 tentang Wakaf.

Peraturan Menteri Agama Republik Indonesia Nomor 34 Tahun 2016 tentang Organisasi dan Tata Kerja Kantor Urusan Agama Kecamatan.

Peraturan Menteri Dalam Negeri (Permendagri) Nomor 6 Tahun 1977 tentang Tata Cara Pendaftaran Tanah Mengenai Perwakafan Tanah Milik.

Badan Wakaf Indonesia (BWI), (2011), Himpunan Peraturan Badan Wakaf Indonesia Cetakan Kedua, Jakarta: Badan Wakaf Indonesia. 
Direktorat Jendral Bimbingan Masyarakat Islam, (2006), Perkembangan Pengelolaan Wakaf di Indonesia, Jakarta: Departemen Agama RI.

Direktorat Jendral Bimbingan Masyarakat Islam, (2013), Himpunan Peraturan PerundangUndangan Tentang Wakaf, Jakarta: Kementrian Agama RI.

\section{Jurnal}

Achmad Arief Budiman, (2011), “Akuntabilitas Lembaga Pengelola Wakaf”, Jurnal Walisongo, Volume 19 Nomor 1.

Etika Rahmawati, (2020), "Pendampingan Pembuatan Akta Ikrar Wakaf Bagi Masjid-Masjid di Wilayah Kecamatan Rasau Jaya Kabupaten Kubu Raya Kalimantan Barat", Al Khidmat : Jurnal Ilmiah Pengabdian Kepada Masyarakat, Volume 3 Nomor 1.

Nurhidayani dkk, (2017), "Pengelolaan dan Pemanfaatan Wakaf Tanah dan Bangunan", Maqdis: Jurnal Kajian Ekonomi Islam, Volume 2 Nomor 2.

Saifuddin Noorhadi. (2005), "Wakaf dalam Perspektif Hukum Agraria Nasional: Kajian Teoritis ke Arah Pengelolaan dan Pendayagunaan Tanah Wakaf Bersifat Produktif-Komersial”, Disertasi. Malang: Program Pascasarjana Universitas Brawijaya.

Sherafat Ali Hasymi, (1987), "Management of Waqf: Past and Present," dalam Hasmat Basyar (ed.), Management and Development of Auqaf Properties, Jeddah: Islamic Research and Training Institute and Islamic Development Bank.

Solikhul Hadi, (2017), "Pemberdayaan Ekonomi Melalui Wakaf", Jurnal Zakat dan Wakaf (Ziswaf), Volume 4 Nomor 2.

Zulfirman, (2003), "Wakaf Dalam Perundang-Undangan di Indonesia”, Makalah Seminar Internasional Wakaf Sebagai Badan Hukum Privat, Diselenggarakan di Medan tanggal 6-7 Januari 2003.

\section{Internet}

Muhammad Zulfikar dan Tasrief Tarmizi , Antara News, Artikel Yasonna: Masyarakat Sadar Hukum dapat Tercipta dari Sosialisasi Hukum, https://www.antaranews.com/berita/2096382/yasonna-masyarakat-sadar-hukumdapat-tercipta-dari-sosialisasi

M.E. Burhanuddin, Meningkatkan Peran dan Fungsi KUA sebagai Ujung Tombak Pengamanan Wakaf, https://www.bwi.go.id/5016/2020/06/24/meningkatkanperan-dan-fungsi-kua-sebagai-ujung-tombak-pengamanan-wakaf/

Situs Kementrian Komunikasi dan Informatika Republik Indonesia, https://www.depkominfo.go.id 


\section{Wawancara}

Wawancara dengan Bapak Mukhsin, S.H.I. Kepala KUA Kecamatan Rasau Jaya, yang dilakukan pada tanggal 04 Agustus 2021 pukul 13.00 WIB.

Wawancara Dosen STIS Syarif Abdurrahman Pontianak Pada tanggal 06 Agustus 2021, jam 10.00 WIB (Ibu Etika Rahmawati, S.H., M.Kn) yang melaksanakan pengabdian kepada masyarakat tentang Pendampingan Pembuatan Akta Ikrar Wakaf di Kecamatan Rasau Jaya, Kabupaten Kubu Raya, Kalimantan Barat. 